\title{
New Legionella Control Options by UV and Violet LEDs for Hospitals and Care Facilities
}

\author{
Martin Hessling $^{1 *}$, Julian Schmid ${ }^{1}$, Katharina Hoenes ${ }^{1}$, Petra Vatter $^{1}$ \\ 'Institute of Medical Engineering and Mechatronics, UIm University of Applied Sciences, Ulm, Germany
}

*Corresponding Author: Martin Hessling, Ph.D., Professor, Institute of Medical Engineering and Mechatronics, Ulm University of Applied Sciences, Albert-Einstein-Allee-55, D-89081 Ulm, Germany. Tel: +49-731-5028602, Email: hessling@hs-ulm.de

Received February 25, 2018; Accepted April 17, 2018; Online Published April 28, 2018

\begin{abstract}
Legionella infections caused by contaminated water are a widespread problem worldwide. Discharge lamps like mercury vapor lamps are widely known for the disinfection properties of their radiation, but they suffer technical disadvantages, like high voltages and toxic content, and are, therefore, not suitable for some infection control applications. New highintensity ultraviolet (UV) and violet LEDs offer new approaches for Legionella control, because these bacteria are significantly light sensitive compared to other pathogens. One of the most important infection pathways is the inhalation of Legionellacontaining aerosols during showering. This problem could be reduced by a single strong UV LED within the shower head, which irradiates the passing water for some milliseconds. This practice can be especially beneficial in hospitals and care facilities. UV light offers only a limited penetration depth, however, even in pure water. To disinfect larger water volumes, e.g., in water dispensers, visible violet LEDs are more appropriate. Unfortunately, up to now, neither approach has been given much attention by potential users.

Keywords: Legionella, Infection Control, Ultraviolet Radiation, Violet Light
\end{abstract}

\section{Introduction}

Legionellae are aquatic bacteria that got their name from the first major outbreak of infection in 1976 at a veterans' meeting of the American Legion. ${ }^{1}$ The most severe legionellosis, the so-called Legionnaires' disease (a severe form of pneumonia), is triggered by Legionella pneumophila when the pathogen enters the lungs through aerosols. It is estimated that this leads to 1500-30000 cases of pneumonia per year in Germany alone. ${ }^{2}$ The so-called Pontiac fever is a milder form of infection, but it has a 10-100 times higher prevalence. $^{3}$ The total number of Legionella infections in Germany, therefore, may be in the range of several hundred thousand cases per year, which is quite a high infection rate considering the German population of approximately 80 million people. Hospitals and care facilities account for only about $4 \%$ of these cases, but the lethal progressions are 3-5 times higher than in other cases. ${ }^{4}$ Important risk factors are a weakened immune system and an age of more than 50 years, which facilitate infection by inhaled aerosols during showering or drinking or when washing surgical wounds. ${ }^{5}$

Due to the multitude of cases and the severity of the possible consequences, new ways are being sought to reduce Legionella in water systems. Unfortunately, the pathogens live in biofilms inside drinking water systems where they are difficult to control with chemical disinfectants or heat. Therefore, it is almost impossible to eliminate Legionella entirely. Recent developments in ultraviolet (UV) and violet LEDs have led to new investigations into their effects on Legionella and opened up new disinfection applications, which appear to be particularly promising for Legionella disinfection.

\section{Effects and Applications of Light on Legionellae 2.1. Ultraviolet Irradiation}

The application of UV radiation, especially the so-called UV-C part of the UV spectrum (UV-C: wavelength 200-280 $\mathrm{nm}$ ), efficiently disinfects; this has been known for more than 100 years. ${ }^{6}$ Its mechanism is based on the destruction of the DNA of undesired microorganisms. ${ }^{7}$ In Schmid et al study, ${ }^{8}$ bacterial solutions containing Legionella rubrilucens were spread on buffered charcoal yeast extract agar and exposed to $254 \mathrm{~nm}$ UV-C radiation from a mercury vapor lamp. Successful disinfection was verified by counting Legionella colonies after incubation and comparing the number of colonies on irradiated agar plates with those on unirradiated reference plates. The obtained result is presented in Figure $1 .{ }^{8}$ On average, a UV-C dose of $1.1 \mathrm{~mJ} /$ $\mathrm{cm}^{2}$ reduces the bacterial count by $90 \%$, which is consistent with the results of two previous studies on other species

Copyright $(2018$ The Author(s). This is an open-access article distributed under the terms of the Creative Commons Attribution License (http:// creativecommons.org/licenses/by/4.0), which permits unrestricted use, distribution, and reproduction in any medium, provided the original work is properly cited. 


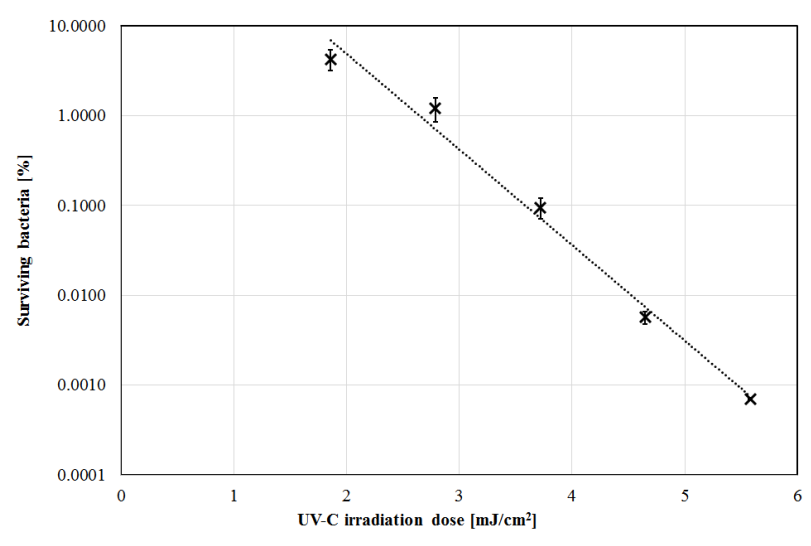

Figure 1. Surviving Legionella rubrilucens After Different UV-C Irradiation Doses (Based on Schmid et $\mathrm{al}^{8}$ ).

of Legionella, including the particularly important species Legionella pneumophila. ${ }^{9}$ Other pathogens often require much higher doses for a $90 \%$ reduction, e.g., Escherichia coli 2.5-7 mJ/cm $\mathrm{cm}^{2}$, Staphylococcus aureus $3.9 \mathrm{~mJ} / \mathrm{cm}^{2}$, Streptococcus faecalis $5.5-6.6 \mathrm{~mJ} / \mathrm{cm}^{2}$, and Adenovirus $20-$ $40 \mathrm{~mJ} / \mathrm{cm}^{2} .9$

This high UV sensitivity of Legionella and the first-time availability of small, high-performance UV-C LEDs in the range of up to $100 \mathrm{~mW}^{10}$ now make the employment of such LEDs for a point-of-use Legionella disinfection system tangible. The most sensible application would be to equip shower heads in hospitals and nursing homes with UV-CLEDs, as depicted in Figure 2. A dose of $1.1 \mathrm{~mJ} / \mathrm{cm}^{2}$ - or a multiple thereof - would already be reached if the passing water was exposed to UV-C radiation for less than one tenth of a second (i.e. substantially more than $90 \%$ of the Legionellae would be inactivated in such a shower head). An exact calculation depends on the angular distribution of the LED emission and the water flow profile, but a rough estimation can be performed assuming a homogeneous irradiation of the tube cross section of, for example, 1 $\mathrm{cm}^{2}$ by a $100 \mathrm{~mW}$ UV-C LED. This would result in an irradiation intensity of $100 \mathrm{~mW} / \mathrm{cm}^{2}$, which would lead to a $90 \%$ reduction in $0.01 \mathrm{~s}$ or a $99.9 \%$ reduction in 0.03 seconds.

\subsection{Violet Irradiation}

UV LEDs are ideal as a point-of-use disinfection system when small amounts of water must be disinfected in the shortest possible time. They will become increasingly important for point-of-use disinfection systems in the future. However, they also have properties that make them less suitable for other applications. These disadvantages include the still relatively high costs of LED, the low penetration depth of about $10 \mathrm{~cm}$ or less even in pure water, and the potential endangerment to human cells or even some sensitive technical materials. Thus, they are less appropriate for disinfection in small tanks. Fortunately, however, there is another disinfection approach available for some other areas of application.

The disinfecting effects of visible violet light with a

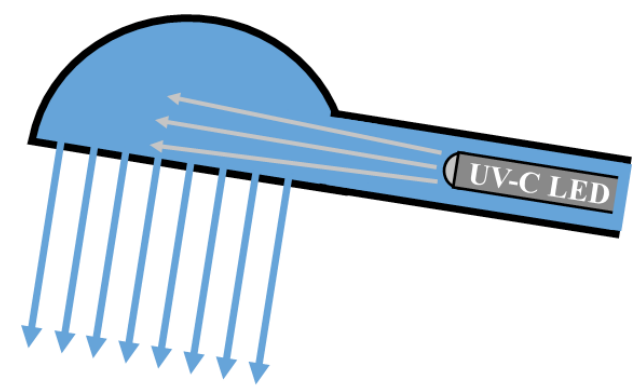

Figure 2. Scheme of a UV-C LED Within a Shower Head.

wavelength around $405 \mathrm{~nm}$ are largely unknown, even among experts. Violet $405-\mathrm{nm}$ light is absorbed in bacteria by so-called endogenous photosensitizers such as porphyrins and leads to the formation of radicals that destroy the bacteria from within. So far, this effect has been confirmed for about 50 bacterial strains. ${ }^{11}$ Figure 3 shows the world's first investigation of the effect of violet 405-nm light on Legionella (L. rubrilucens), ${ }^{12}$ which proved that Legionellae are also killed by this visible light. The average dose for a $90 \%$ reduction with $405-\mathrm{nm}$ light is about $25 \mathrm{~J} /$ $\mathrm{cm}^{2}$. This means that Legionellae are also quite sensitive to visible light, and their sensitivity is even higher compared to that of other bacteria as reported in the literature. Observed photoinactivation doses are $75.6 \mathrm{~J} / \mathrm{cm}^{2}$ for $E$. coli, $35.9 \mathrm{~J} / \mathrm{cm}^{2}$ for S. aureus, and $96 \mathrm{~J} / \mathrm{cm}^{2}$ for $S$. faecalis for a $90 \%$ reduction. ${ }^{11}$

Notably, the necessary doses of radiation are considerably higher than for UV-C radiation - about 4 orders of magnitude - and are, therefore, not reached in fractions of a second. Thus, visible violet light is not suitable for a pointof-use disinfection system in shower heads or water taps. Violet LEDs, however, are inexpensive, energy-efficient, offer a penetration depth of several meters in water, and provide radiation that is usually harmless to human tissue and many technical materials. For this reason, there are useful fields of application wherever longer irradiation periods are possible, such as in tanks or in the water dispenser illustrated in Figure 4.

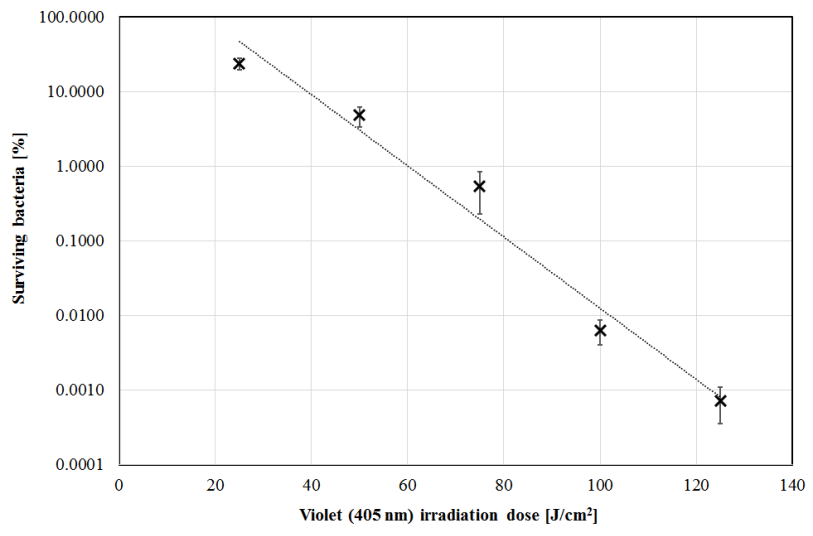

Figure 3. Surviving Legionella rubrilucens After Different Doses of Violet (405 nm) Irradiation (Based on Schmid et $\mathrm{al}^{12}$ ). 


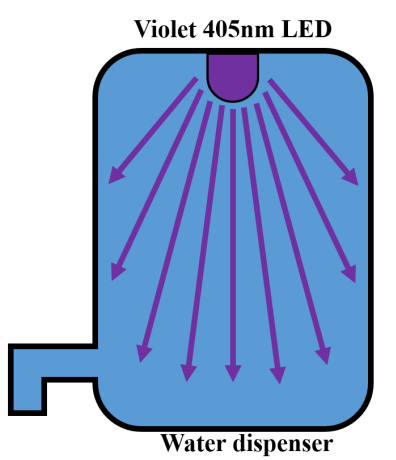

Figure 4. Scheme of a Violet 405-nm LED in a Water Dispenser.

\section{Conclusion}

If the annual infection figures from Germany were extrapolated to the whole world, this would result in many millions of Legionella infections every year. Therefore, new water disinfection approaches are urgently needed. The current basic research on L. rubrilucens that is in agreement with the published complementary results of other authors reveals that Legionellae seem to be very sensitive to UV-C irradiation and to visible violet light. The combination of new high intensity UV-C LEDs with new highly efficient, low-cost violet LEDs offers an opportunity to integrate small Legionella control measures within existing water networks or other water-containing systems. Probably one of the most important actions would be to equip the shower heads in hospitals and care facilities with powerful UV-C-LEDs in order to protect their especially endangered immune-compromised inhabitants.

\section{Authors' Contributions}

All authors contributed equally to this research.

\section{Conflict of Interest Disclosures}

No conflicts of interest are declared.

\section{Ethical Approval}

Not applicable.

\section{Acknowledgments}

This work was financially supported by the German Federal Ministry of Economics and Technology within the ZIM project “Clean Spring” (grant number KF2186208CR4).

\section{References}

1. Brenner DJ, Steigerwalt AG, McDade JE. Classification of the Legionnaires' disease bacterium: Legionella pneumophila, genus novum, species nova, of the family Legionellaceae, familia nova. Ann Intern Med. 1979;90(4):656-658. doi:10.7326/0003-4819-90-4-656.

2. von Baum H, Luck C. Ambulant erworbene Legionellenpneumonie. Bundesgesundheitsblatt Gesundheitsforschung Gesundheitsschutz. 2011;54(6):688-692. doi:10.1007/s00103-011-1287-0.

3. Robert-Koch-Institut. Pontiac-Fieber: Diagnostische Möglichkeiten zum Nachweis von Legionellen als Ursache. Epidemiologisches Bulletin; 2011. https://www.rki.de/DE/Content/Infekt/EpidBull/ Archiv/2011/Ausgaben/28_11.pdf?__blob=publicationFile.

4. Robert-Koch-Institut. Legionärskrankheit in Deutschland (2001 bis 2013). Epidemiologisches Bulletin; 2015. https://www.rki. de/DE/Content/Infekt/EpidBull/Archiv/2015/Ausgaben/13_15. pdf?_blob=publicationFile.

5. Bartram J. Legionella and the prevention of legionellosis. Geneva: World Health Organization; 2007.

6. Henri V, Helbronner A, Recklinghausen M de. Stérilisation de grandes quantités d'eau par les rayons ultraviolets. Compt Rend Acad Sci. 1910;1910(150):932-934.

7. Wacker A, Dellweg H, Weinblum D. Strahlenchemische Veranderung der Bakterien-Desoxyribonucleinsaure in vivo. Naturwissenschaften. 1960;47(20):477. doi:10.1007/ BF00638304.

8. Schmid J, Hoenes K, Rath M, Vatter P, Hessling M. UV-C inactivation of Legionella rubrilucens. GMS Hyg Infect Control. 2017;12:Doc06. doi:10.3205/dgkh000291.

9. Chevrefils G, Caron E, Wright H, et al. UV dose required to achieve incremental Log inactivation of bacteria, protozoa and viruses. IUVA News. 2006;8(1):38-45.

10. Inoue SI, Naoki T, Kinoshita T, Obata T, Yanagi H. Light extraction enhancement of $265 \mathrm{~nm}$ deep-ultraviolet lightemitting diodes with over $90 \mathrm{~mW}$ output power via an AIN hybrid nanostructure. Appl Phys Lett. 2015;106(13):131104. doi:10.1063/1.4915255.

11. Hessling M, Spellerberg B, Hoenes K. Photoinactivation of bacteria by endogenous photosensitizers and exposure to visible light of different wavelengths - a review on existing data. FEMS Microbiol Lett. 2017;364(2). doi:10.1093/femsle/ fnw 270 .

12. Schmid J, Hoenes K, Rath M, Vatter P, Spellerberg B, Hessling M. Photoinactivation of Legionella Rubrilucens by Visible Light. Eur J Microbiol Immunol (Bp). 2017;7(2):146-149. doi:10.1556/1886.2017.00006. 